\title{
They danced to all songs : double employments and conflicts of interest within academic computer science.
}

\author{
Camille Akmut
}

\begin{abstract}
Part 1 of a research on double employments and conflicts of interest within academic computer science, their effects on that science, both in research and in education, and a comparison with and generalization of similar phenomena in other sciences.
\end{abstract}




\section{Introduction : Once a Goldman Sachs employee, always...}

In one of his recent talks, economist Yanis Varoufakis had remarked, and observed : "Once a Goldman Sachs employee, always a Goldman Sachs employee." "This came in the context of a conversation with political activist Maria Masha Alyokhina ${ }^{2}$, who herself had just noted there were "no ex-KGB" (alluding to the past employments of Russian president Vladimir Putin within both KGB and its successor FSB).

After them, we can say : Once a Google employee, always a Google employee (Once a Googler, always a Googler). And, similarly for Facebook and Microsoft, among many other such places.

Our successors will do the same about their successors.

This research, long deferred, and even deleted, will now be re-written and published in three parts instead : 1 . double employments 2 . computer science publications 3 . effects on sciences. ${ }^{3}$

In the following, we give a list of computer scientists encountered in our research of almost 3 years and over 30 publications :

These gentlemen and gentlewomen saw no qualms in working for these various companies : They saw no moral dilemma whatsoever, no conflicts of interests, did not think - or did not care.

Thus, we have no qualms either in putting them inside this research :

They danced, we laughed : They turned us into 'big data'? We do the same to them. They create closed systems? We enclose them in ours.

As we have already written, however, the effects of such employments are many : once an employee of these companies, they remain an employee of them.

They take back home - to their universities, and students, and publications - the modes and ways of thinking and behaving (ethos or habitus) acquired in these same various places : among them a tendency towards non-critical and superficially non-political research.

When listening to them long enough, you will note they have adopted up to the language of their former employers : they don't say "colleagues" anymore, they say "co-workers" instead. And, when will they start calling their offices "cubicles", in revealing and identifying Freudian slips?

One of these professors even went as far as exchanging his chair and professorship for a "software engineer" position... Such buffooneries cannot be invented, and we must call them so to render them accurately, we have no choice.

But, we have showed them, and continue to show them, that - whether they want it, like it or not - politics are everywhere in their science.

\footnotetext{
${ }^{1}$ Alyokhina and Varoufakis 2018.

${ }^{2}$ Member of feminist punk rock band Pussy Riot.

${ }^{3}$ The increasingly harder parts are kept for last.
} 
our conceptions (...) [are] inherited from dominant views, those of the manufacturers of hardware, makers of commercial software, large, enterprise corporations, but not least also from academic computer scientists, an ever-increasing portion of whom come from or have significant ties with these same groups, whose rules, disciplines, sets of thinkable and un-thinkable, permissible and non-permissible, acceptable and non-acceptable, they then bring home, in thought or unthought form, in the abstract form of grades, the classes they teach, the topics they select (or prefer to confine themselves to), the textbooks they pick, and in the way of the graduate students they select and do not select, colleagues (co- workers) they promote and do no promote, and the others they publish and do not publish, and up to the things they themselves publish and encourage their students to publish, or discourage. ${ }^{4}$

This is unavoidable : computer science, had they read their forefathers more closely, they would know, deals with "computers and the phenomena surrounding them". Primary among them : people (incl. themselves).

These "purists", as we have called them disparagingly elsewhere, are still the alchemists of their days, the non-atomist scientists described by Kuhn.

They have not the first idea about where their science is going : perhaps it never occurred to them.

The comparison with bankers is fitting : corporate software engineers, we repeat, if not computer scientists, have a good chance of becoming the bankers of tomorrow : some of them have done much towards earning their trade, if not yet science, this reputation. We may think of them in the same way one day - and, such is not a good one.

\footnotetext{
${ }^{4} 2019: 22$
} 


\section{Programming Languages}

Description : these functional programmers and theorists are obsessed with "purity" in their languages, but forget the 'world outside'. Others understand the intricacies of operating systems, but not that of their own.

$\begin{array}{lll}\text { Person } & \text { Company } & \text { Other affiliation } \\ \text { Ralf Lammel } & \text { Facebook } & \\ \text { Erik Meijer } & \text { Microsoft, Facebook } & \text { Koblenz-Landau } \\ \text { Bryan O'Sullivan } & \text { Facebook } & \text { Stanford Delft } \\ \text { Simon Peyton Jones } & \text { Microsoft } & \text { Glasgow } \\ \text { Rob Pike } & \text { Bell Labs, Google } & \\ \text { Ken Thompson } & \text { Bell Labs, Google } & \\ \text { Don Stewart } & \text { Facebook }\end{array}$

\section{Artificial Intelligence / Machine Learning}

Description : they preferred exploring the depths of artificial intelligence, because it was easier than their own.

$\begin{array}{lll}\text { Computer scientist } & \text { Company } & \text { Other affiliation } \\ \text { Christopher Bishop } & \text { Microsoft } & \text { Edinburgh, Cambridge } \\ \text { Francois Chollet } & \text { Google } & \\ \text { Geoff Hinton } & \text { Google } & \text { Toronto } \\ \text { Andrej Karpathy } & \text { Tesla } & \text { Stanford } \\ \text { Yann LeCun } & \text { Facebook } & \text { College de France }\end{array}$

\section{Cryptography}

Description : deciphering the secrets of their hearts and minds is faster than their algorithms.

$\begin{array}{lll}\text { Computer scientist } & \text { Company } & \text { Other affiliation } \\ \text { Nadim Kobeissi } & \text { Microsoft } & \text { INRIA }\end{array}$




\section{Non-conclusion}

Much talk these days is of "de-googling", or "ungoogled", removing "blobs", or even "freeing" software :

But, there would be no need to do any of these things, if they had "degoogled" their computer scientists and engineers first. A task infinitely harder, of course :

A task they may soon find they are not equipped with the right tools to accomplish.

Computer science is a social science : and, you have much to learn. 


\section{References}

- 2019. "A User-Defined Web. And, on Systems modification in general."

—. 2019b. "Tech dogma \# 1 : The Great Separation, between the "technical" and the "political". Documents towards a history."

—. 2019c. "Big Boy. Smarts So Big, Senses So Little: The "theoretical" science of the respectable physicist Prof. Dr. J. Robert Oppenheimer of the Institute for Advanced Study in Princeton, and 60,000 Hiroshima funerals"

Alyokhina, Maria Masha and Varoufakis, Yanis. 2018. "Pussy Riot's Maria Alyokhina with Yanis Varoufakis at the Edinburgh International Book Festival". /watch?v=esEZA-62Au8 